\title{
Dynamic synergy analysis in international business: the concept and application to two players China and Russia
}

\author{
Prof Dr M S S El Namaki, \\ Dean, Victoria University, School of Management, Switzerland. \\ Dean (Retired) Maastricht School of Management, MSM, And The Netherlands. \\ oScholedge International Journal of Management \& Development (ISSN 2394-3378), Vol.03, Issue 07 (2016) pg129-136. \\ Published by: Scholedge R\&D Center [www.theSCHOLEDGE.org] [Email: editorial@thescholedge.org]
}

\section{The problem}

There are two ways to conduct economic, and possibly political, business between countries. The first is conventional search for country present day competitive advantage (Porter, 1990). Yet competitive advantage is transient, not sustainable (Forbes, 2.6.2013). And competitive advantage could relate to yesterday's industries not today's arenas. A more plausible search is that for strategic synergy or a situation where the two countries whole is greater than the sum of individual country parts. The later, the synergy route, places emphasis on strategic longer term complementarity or synergy between the two countries rather than a transient advantage.

The following article addresses the second scenario.

It projects a model for the identification of the term driving forces of two economies, tracing their respective future synergies and deriving synergy-rooted strategies. The article goes on to apply the model to two countries: China and Russia, being contemporary illustrations of a largely politically driven search for economic synergy.

The model could have conceptual as well as applied dimensions. Conceptually, it provides a theoretical framework for present day international business concepts. Operationally it could lead to specific strategies, and venues, for economic and business engagement between countries.

\section{Dynamic synergy: the concept}

Dynamic synergy analysis is a process whereby future driving forces of two economies are juxtaposed in order to identify areas of synergy and create a foundation for cross country strategic behavior. Synergy connotes, in this case, interaction between two or more forces in a way that leads to a combined output that is greater than the sum of the individual components. Synergy could also be viewed as the creation of a whole that is greater than the simple sum of its parts.

Future driving forces could be capital related, technology related or productivity related. Capital could become a driving force of economic growth if there are capital assets enough to drive the process and capital markets mature enough to create a dynamic force. Capital market maturity here is measures in terms of instruments, institutions, players, policies and flows. Technology could become a driving force if parameters of technological innovation measure up to global innovation standards. Those standards could relate to the volume of patents, patent product and process conversion, patent process conversion and. Productivity is a depended function depending on several inputs including capital and technology. 
Driving forces could be understood if one is to consider the basic premise that growth of economic output is, essentially, a function of the volume of inputs and the quality of the conversion process. Capital and technology are the inputs and productivity is the output and all three of them drive economic growth.

The following graphic representation of the concept projects country future driving force attributes along the $y$ and $x$ axis. The $y$ axis represent the economic driving forces of country $A$ and the $x$ axis represent the economic driving forces of country B. Synergies between the two respective country specific drivers of economic growth feature in point of intersection between any two drivers.

\section{Figure (1)}

\section{The dynamic synergy concept}

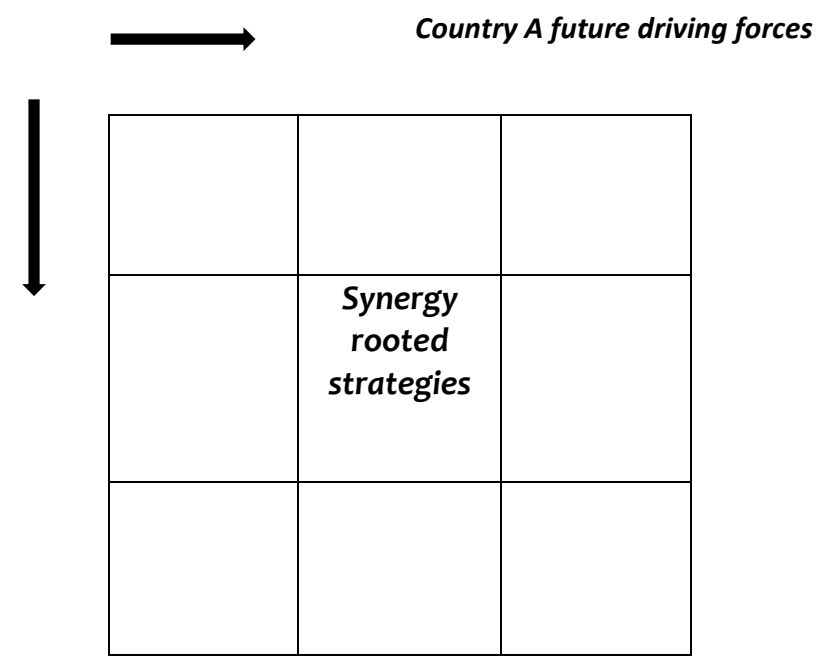

\section{Case application: China and Russia}

\section{Case one: China}

Long and medium term economic driving forces in china cover a wide range but one can identify five key forces. Those include the One Belt One Road initiative (OBOR), the Asian Infrastructure Investment Bank (AIIB), the internationalization of the RMB, the globalization of capital markets and the technology surge.

\section{Eurasia economic integration : One Belt One Road (OBOR) policy initiative}

The Initiative is a development strategy stressing connectivity, cooperation and market penetration within the Eurasia region. It consists of two main components, the land-based "Silk Road Economic Belt" (SREB) and oceangoing "Maritime Silk Road" (MSR). Chinese President Xi Jinping introduced the initiative, in October 2013 as a vision that connotes "Peace and cooperation, openness and inclusiveness, mutual learning and mutual benefit" and unimpeded trade and financial integration. The initiative would in reality provide a renewed framework for China's economic growth away from 
the almost chronic dependence on US and EU markets and closer to the emerging economies of the region.

The maritime segment of the initiative envisages a route that runs through the Indian Ocean and connects through the Suez Canal to European markets.

\section{The internationalization of the Renminbi (RMB)}

The Renminbi (RMB), China s national currency, is to be included in the basket of currencies that make up the IMF's Special Drawing Right, or SDR according to a recent decision by the IMF's Executive Board (IMF, 2016). A revised SDR basket will assign a $41.73 \%$ weight to the USA and $10.9 \%$ weight to the Chinese RMB. It is a new formula whereby the weights of the currencies in the SDR basket are based on several criteria including the value of the issuers' exports and the amount of reserves denominated by currencies of other monetary authorities. Internationalization of the RMB will lead, soon, to the RMB becoming a medium for settlement of trade transactions, issue of Culminated bonds, offer of offshore Renminbi deposit accounts and setting up local currency bilateral swap lines with other central banks. Actually the OBOR initiative allows for RMB bilateral swap agreements with nations stretching along the two routes. The United Arab Emirates and Qatar are included in those agreements but not Egypt.

\section{Dominating global infrastructure finance : AllB}

Asia Infrastructure Investment Bank (AIIB) was created in late-2014 as an element within the OBOR grand strategy. It provides, according to the Chinese government, a response to Asia's large future infrastructure financing gap, which has been put at near $\$ 8$ trillion between 2010 and 2020. It will also provide novel investment assessment criteria. More than 60 countries have either subscribed to the capital base or sought association. It is viewed by some as a complement to the existing mosaic of international monetary organization and by others as an outright competitor. Reservations against Bretton Woods institutions - the IMF, the World Bank and, to some extent, the World Trade Organization, have, as the argument goes, played a role in the emergence of the AllB.

\section{Leadership of global capital markets}

Despite occasional volatility China's capital market is in the way to becoming the world's largest and most dynamic. Domestic capital input, foreign capital inflows and Chinese capital outflows are driving the process. Chinese equity markets stood at US\$8.5 trillion in market capitalization (2015 data). The bond market, put at US $\$ 6.0$ Billion, is the world's third-largest after the US and Japan and is larger than the entire Euro zone. Capital inflow is subject to regulation but there is strong established pattern driven by multinational corporations, investment funds and insurance companies. Chinese global $\mathrm{M}$ and $\mathrm{A}$, and the resulting capital outflow, is carried out by Chinese sovereign investment funds, Chinese International Corporations and individual investors. Worldwide cross-border merger and acquisition activity which has reached $\$ 132.7$ billion so far in 2016, was primarily driven by Chinese acquisitions (Reuter, Feb 5, 2016). Those acquisitions focused , in the first place, on technology, brands, financials, and real estate. (HSBC Malaysia, 07 October 2015)

This is a development that is likely to continue, and strengthen, in the course of the coming decade. 


\section{The emergence of Chinese disruptive technologies}

There are several crucial technology domains where China is already outpacing the United States. Technologies where superiority is claimed include high speed rail, computing, high voltage transmission, advanced coal technology, nuclear technology, renewable energy and solar energy. China's own innovation machinery is enhancing this trend. The year 2014 and for the fourth consecutive year, saw China recording more patent applications than any other country in the World. The number of invention patent applications filed with the State Intellectual Property Office (SIPO) in 2014 stood at 928,000 or $12.5 \%$ above the 2013 level. The number of invention patents per 10,000 Chinese individuals reached 4.9. In the same year. (China Daily, 23.2.2015).

\section{Case two: Russia}

The economic future of Russia will, most probably, be defined by five driving forces. Those include the greater reach of Russian energy, the expansive role of minerals and metals industry, and the proliferation of the defense industry, the restructuring of capital markets and the advent of new supply chains. Analysis takes into consideration anti-Russian sanctions imposed in the past few years and the tangible recent re-bouncing of the Russian economy (The Economist, Apr 15th 2015) .

\section{The greater reach of the energy industry}

Oil and gas have been key drivers of the Russian economy for years and are very likely to continue to play that role and provide strategic cross country synergy. Recent political skirmishes and shifts in oil market conditions will undoubtedly have an impact but there are strong indications that those would not undermine the key role of energy in the Russian economy. Geopolitical demand for energy, including LNG, from neighbors along the eastern border will, very likely, boost the country's LNG potential as a niche energy producer for Asian countries. Gazprom long term commitment to supply, as from 2018, up to 38 billion cubic meter of gas to China is a typical example of that. Work currently underway on several Chino-Russian pipelines as well as the joint operation of refineries is yet another example. Acquisitions by Russian domestic energy giants in South and East will enhance this energy advantage even further. ( WEF Jan 2013). And its movement downstream thus producing chemicals and refined products will add an advantage within this Far East scenario.

\section{Further global penetration of metals and mining.}

Russia has substantial reserves of nearly all major industrial raw materials and is one of the world's largest mineral producers, accounting for about $14 \%$ of the world's total mineral extraction. Metals account for about $14 \%$ of Russia's total exports, second only to the oil and natural gas industry. Raw metals and aluminum comprise the majority of the country's metal exports. Most of Russia's metal production is exported. A near 90 percent of Russian exports to the USA are minerals or other raw material. The country is also the largest explore of diamonds with an estimated World market share of $25 \%$ (2013 data). Russia's proved iron ore reserves are the biggest in the world, accounting for about $15 \%$ of the total iron ore production. Russia holds the world's second largest recoverable coal reserves and is the world's third largest exporter of black coal. Russia's metals and mining sector is the country's largest private industry. Increased infrastructure spending in China, bides well for Russia's metals and mining industry (BRIC Spotlight Report, January 2011).

\section{Proliferation of the defense industry}

Russia s defense industry leads, globally, in terms of exports and internally in terms of employment (20 percent of manufacturing employment) and contribution to GDP (6\% 2011 ). Russia's military equipment exports cover a wide range from fighter jets and air defense systems to battle tanks and 
armored vehicles. The 2017-2021 period is expected to witness increased demand for several systems including command control computers, communications intelligence equipment, surveillance and reconnaissance systems, transport air crafts, mufti-role air crafts, and submarines. Russian military spending is anticipated to reach US\$78.4 billion by 2021 with a focus on modernizing advanced defense systems and border security measures.

The Russian defense industry is driven by domestic criteria as well as a regional arms enhancement drives especially those of China. Asian countries have been, and continue to invest in advanced military gear including combat aircraft, unmanned aerial vehicles, submarines, and surface vessels, long range ballistic and cruise missiles (The American, October 25, 201) This will very likely constitute a potent driving force for the Russian defense industry.

\section{Restructuring of the finance industry}

Russia's finance industry woes are well known and could be looked at as a "reverse" driving force. Russia continues to adjust to an adverse external environment triggered by lower oil prices and international sanctions, twin shocks that have resulted into a 3.7\% decline in GDP in 2015. Response through, among others, a flexible exchange rate, has presented Russia with an opportunity to enhance competitiveness in traditional exports and initiate a drive to diversify away from primary commodities into innovative and advanced technology products. GDP growth is expected to resume at a modest rate of 1.1 percent in 2017. (World Bank Apr 08, 2016 ).

Regional political alliances, are casting a shadow on this scenario, however. Russian Chinese rapprochement in currency and capital market issues is leading to a relative contraction in the role of US \$ as global transaction currency. Russia's second biggest financial institution, VTB, has, for instance, concluded an agreement with the Bank of China to bypass the dollar in bilateral dealings and settle resulting obligations in domestic currencies. The RMB, as a result, was adopted in China's purchases of Russian hydrocarbons as well as China's $\$ 12$ billion five year loan to Russia for the Russian Chinese pipeline "Force of Siberia". This functional alliance is taking several other dimensions including a new "swift" arrangement and innovative capital market instruments.

\section{Logistics and transportation}

Russia's geographical location creates a physical advantage inherent in a role as the connecting bridge between Europe and the Asia-Pacific region. Russia's Short and economically viable transportation arteries lie at the heart of this advantage. Prospects of creating a viable and intense cross Arctic transportation channels for international goods as well as regional hydrocarbon outputs has induced future planning commitments. Arctic mineral resource development requires, after all, reliable transportation infrastructure for both access and output outflow.

At present, the NSR freight transit largely consists of gas condensate and oil products shipments, with large-capacity tankers accounting for the majority of the transit cargo traffic. Other minerals can also be transported from the Arctic region by sea.

The Arctic region has a special significance for realization of Russia's potential in the transportation area. It provides a good opportunity for becoming one of the world's key transportation hubs. A hub of special significance to the Asia Pacific region(Arctic Institute, October 31, 2014) (Voice of Russia, June 27,2016) 


\section{The analysis}

A picture of possible dynamic synergy between China and Russia is provided in the following figure. Driving forces of both economies are projected and derived areas of congruence are identified, Analysis, again, takes into consideration anti-Russian sanctions and the tangible re-bouncing of the Russian economy (The Economist, Apr 15th 2015) .

Areas of congruence and synergy could extend of a rather wide range but the ones that come to the forefront are the following:

1. China's Eurasia trade and finance expansion and Russia's logistics and transportation plans

2. China's capital market prowess coupled with Russia's impending capital market reform.

3. China's internationalization of the RMB combined with a position of leadership in global capital markets congrues with Russia's energy and trade growth.

4. Chinese disruptive technologies and Russia's modernization of the defense industry.

It goes without saying that further analysis would lead to a more complete picture.

Figure (2)

Areas of possible strategic synergy

\begin{tabular}{|c|c|c|c|c|c|}
\hline Russia & $\begin{array}{l}\text { Eurasia } \\
\text { economic } \\
\text { integration : } \\
\text { OBOR }\end{array}$ & $\begin{array}{l}\text { The } \\
\text { internationa } \\
\text { lization of } \\
\text { the RMB }\end{array}$ & $\begin{array}{l}\text { Leadership } \\
\text { of global } \\
\text { capital } \\
\text { market }\end{array}$ & $\begin{array}{l}\text { Chinese } \\
\text { Disruptive } \\
\text { technology }\end{array}$ & $\begin{array}{l}\text { Global } \\
\text { infrastructu } \\
\text { re finance } \\
\text { AllB }\end{array}$ \\
\hline $\begin{array}{l}\text { The greater } \\
\text { reach of the } \\
\text { energy industry }\end{array}$ & & $\mathbf{x}$ & & & $\mathbf{x}$ \\
\hline $\begin{array}{l}\text { Global } \\
\text { penetration of } \\
\text { metals and } \\
\text { mining industry. }\end{array}$ & & & & & $\mathbf{x}$ \\
\hline $\begin{array}{l}\text { Proliferation of } \\
\text { defense industry }\end{array}$ & & $\mathbf{x}$ & & $\mathbf{x}$ & \\
\hline $\begin{array}{l}\text { Restructuring of } \\
\text { finance industry }\end{array}$ & & $\mathbf{x}$ & $\mathbf{x}$ & $\mathbf{x}$ & $\mathbf{x}$ \\
\hline $\begin{array}{l}\text { Logistics and } \\
\text { transportation }\end{array}$ & $X$ & & & $\mathbf{x}$ & $\mathbf{x}$ \\
\hline
\end{tabular}




\section{Summary and conclusions}

There are two ways to conduct economic, and possibly political, business between countries. The first is conventional search for country present day competitive advantage, but competitive advantage is transient and not sustainable. Deeply ingrained structures and systems designed to extract maximum value from a competitive advantage become a liability when the environment requires an agility compatible with the rapidly changing opportunity landscape. A more plausible search is that for strategic synergy or a situation where the two countries whole is greater than the sum of individual country parts. The later, the synergy route, places emphasis on strategic longer term complementarity or synergy between the two countries rather than a transient advantage.

This article addresses the second scenario.

It projects a model for the identification of term driving forces of two economies, tracing their respective future synergies and deriving synergy-rooted strategies. Two case countries: China and Russia, were chosen to illustrate the concept, a choice driven by present day events and the high probability of existence of genuine synergies. China's longer term driving forces include the One Road One Belt initiative, the evolving leadership of global capital market, China's emerging disruptive technologies, the RMB as a reserve currency and the pioneering role of the AllB in global infrastructure finance. Russia's longer term driving forces, on the other hand, include the proliferation of the defense industry, the expanding reach of the energy industry, the restructuring of the finance industry, the development of the transportation and logistics industry as well as the expansion of the metal and minerals industry. A combination of these forces would lead to a wide range of synergy-rooted strategies that could be based, for instance, on China's Eurasia trade and finance expansion and Russia's logistics and transportation plans or China's capital market prowess and Russia's impending capital market reform.

The model could have conceptual as well as applied dimensions. Conceptually, it provides a theoretical framework for present day international business concepts. Operationally it could lead to specific strategies, and venues, for economic and business engagement between countries.

\section{References}

- Chinese Renminbi to Be Included in IMF's Special Drawing Right Basket, IMF Survey, December 1, 2015,

- Mapping China's future growth -The 'One Belt, One Road' initiative, HSBC Malaysia , 07 October 2015

- Navigating China's capital markets - Opportunities and trends, HSBC Malaysia, 07 October 2015

- http://www.voxeu.org/article/renminbi-will-become-reserve-currency-within-next-decade.

- China M\&A flurry drives cross-border activity to 11-year high, Reuters, Feb 5, 2016.

- China Daily, Daily China tops patent applications list in 2014, 23.2.2015.

- Rodrigues A N, the Petro Yuwan versus Dollar Hegemony, Global Research, May 20, 2016.

- Future of the Russian Defense Industry-Market Attractiveness, Competitive Landscape and Forecasts to 2021, PR News-wire NEW YORK, May 11, 2016.)

- Friedberg A"Asia emerges as center of gravity in the international system" The American, October 25, 2014

- Russia Overview - World Bank Apr 08, 2016

- Future of the Russian Defense Industry - Market Attractiveness, Competitive Landscape and Forecasts to 2021 - The Business Journal 6/22/2016

- Russia's Defense Industry: Breakthrough or Breakdown? ISN Zurich 6 March 2015.

- Guidelines for the development of the Russian Financial Market 
In 2016-2018, BANK OF RUSSIA, 2016.

- "The Arctic region as a key global transportation hub of the future, The Voice of Russia, 6/27/2016.

- Porter E M, the Competitive Advantage, of Nations, HBR, MARCH-APRIL 1990.

- The Russian financial rally Unfair, The Economist, Apr 15th 2015,

- "It's Official! The End Of Competitive Advantage", - Forbes , June 2,2013)

- Scenarios for the Russian Federation WEF Jan 2013

- BRIC Spotlight Report "Sitting on a Gold Mine: Metals and Mining in Russia", Thomas White International, Ltd January 2011).

- Scenarios for the Russian Federation WEF Jan 2013

- Humpert $M$ “ Arctic Shipping Potential Along the Northern Sea Route” Arctic Institute, October 31, 2014 